DOI: https://doi.org/10.46630/bs.1.2019.03

UDK 911.375.6(497.11-12)

Катарина Миленковић ${ }^{1}$

Душан Стаменковић

Универзитет у Нишу

Филозофски факултет

\title{
НАЗИВИ УЛИЦА У ПОГРАНИЧНИМ МЕСТИМА ИСТОЧНЕ И ЈУГОИСТОЧНЕ СРБИЈЕ ${ }^{2}$
}

\begin{abstract}
Резиме
Основни задатак овог рада је да истражи топониме из перспективе ономастике и социолингвистике у два места на граници између Србије и Бугарске (Босилеград и Димитровград), као и два места на граници између Србије и Румуније (Доњи Милановац и Велико Градиште). Ради се о истраживању рађеном на корпусу који се састоји од назива свих улица изабрана четири места. На основу типологије топонима предложене од стране Тента и Блера (Tent \& Blair, 2011), и одређивања изворног референта, рад нуди одговарајућу класификацију назива улица. Уз одређене специфичности и изузетке, налазимо да називи улица у пограничним областима осликавају потребу за очувањем и истицањем како српског културног и историјског наслеђа, тако и културног и историјског наслеђа локалних заједница у овим местима.

Кључне речи: назив улице, топоним, именовање, пограничје, идентитет.
\end{abstract}

\section{УВОД}

Овај рад настоји да истражи имена улица из перспективе ономастике и социолингвистике у два места на граници између Србије и Бугарске (Босилеград и Димитровград), као и два места на граници између Србије и Румуније (Доњи Милановац и Велико Градиште). Примереном методологијом биће сагледане социјалне и културолошке димензије у називима улица сваке општине понаособ. Претпоставља се да називи улица осликавају наглашену потребу за очувањем сопственог националног, културног, регионалног итд. идентитета, као саставног дела живота у пограничном појасу. Коришћењем трагова културе уткане у имена и обичаје именовања, биће уједно реконструисано и српско и мањинско наслеђе у овим пограничним областима.

Изабрани градови налазе се у пограничним областима Србије и Бугарске и Србије и Румуније, и то са приближним бројем становника (један већи и један мањи у обе области, са бројем становника у распону од 2000 до 6000). На званичној презентацији општине Босилеград (Cajm општине Босилеград, 2019), наводи се да Босилеград представља седиште општине Босилеград у Пчињском округу. Овај град на крајњем југоистоку Србије налази се недалеко од границе пре-

\footnotetext{
1 k.milenkovic-13962@filfak.ni.ac.rs

2 Припремљено у оквиру пројекта Одрживост идентитета Срба и националних мањина у пограничним општинама источне и југоисточне Србије (179013), који се изводи на Универзитету у Нишу - Машински факултет, а финансира га Министарство просвете, науке и технолошког развоја РС.
} 
ма Бугарској на истоку и Македоније на југу. Смештен је у долини реке Драговиштице која горњим током протиче кроз Бугарску, а од граничног прелаза Рибарци удаљен је 12 километара. Град почиње да добија садашње обрисе почетком 20. века услед изградње мале хидроцентрале, а данас поседује неколико индустријских објеката за производњу текстила и прераду дрвета. Услед недовољно развијене привреде и вишегодишње стагнације, демографска структура становништва је неповољна, а депопулација прилично изражена. Према попису из 2011. године, Босилеград је имао 2624 становника, од тога преко 70\% Бугара, а знатно мање Срба (11\%) и осталих мањинских група (Станковић, 2016: 616-617).

Према подацима са интернет презентације општине Димитровград (Сајт општине Димитровград, 2019), територија Димитровграда налази се у југоисточном делу Србије и смештена је у источном пределу Пиротског округа у горњем току реке Нишаве. Димитровград је погранично место према Бугарској, и општинско средиште у источном делу Србије под Старом планином. Још су стари Римљани увидели повољан географски положај овог места, јер је ту некада пролазио њихов важан војнички пут, Via militaris. Стратешки положај Димитровграда није промакао ни Турцима, који у 16. веку ту граде конак Сулејмана Величанственог, приликом његовог похода на север. Димитровград је некада био познат под именом Цариброд, и служио је као гранична станица на Цариградском друму, да би касније постао бугарска погранична станица. Након Првог светског рата, ушао је у састав наше тадашње државе, а после ослобођења у Другом светском рату, добија садашњи назив у част вође бугарске комунистичке партије Георги Димитрова. Данас кроз Димитровград пролази међународно и међуконтинентално значајна пруга Београд-Ниш-Софија-Истанбул, а изградњом Коридора 10 требало би да се отворе нове привредне могућности. Након пуштања у рад пруге Београд-Софија, град је почео са развојем пољопривреде, сточарства, занатства, трговине, али и културе. У граду се одвијају културне манифестације које су познате по равноправној употреби бугарског и српског језика. Поред тога, од посебног значаја за друмски саобраћај јесте Градина, један од наших најопремљенијих граничних прелаза са високом годишњом фреквенцијом возила. Према попису из 2011. године насељавало га је 6278 становника, са Бугарима као највећом етничком групом (преко $50 \%$ ), за којом следе Срби (близу 30\%) и остале мањине (Станковић, 2016: 350-352).

На званичној интернет презенатацији општине Мајданпек (Cajm опитине Мајданпек, 2019), наводи се да је Доњи Милановац градско насеље у Борском округу на самој обали Дунава, непосредно у близини веома значајног археолошког налазишта Лепенски Вир, које је уједно и центар националног парка Ђердап. Узводно од града, смештена је хидроелектрана Ђердап са пограничним прелазом и путем ка Румунији, а сам град представља важно пристаниште и најпосећенији туристички центар ђердапског сектора Дунава, односно Ђердапског језера, са великим бројем регистрованих туриста и ноћења. Низводно 
од Доњег Милановца, у најупечатљивијем делу Ђердапске клисуре, Казану, налазе се остаци Трајановог пута из римског доба. Доњи Милановац је некада био центар Поречког краја, где је рођен Миша Анастасијевић, трговац, бродовласник и дунавски капетан. Као познати добротвор, Београду је поклонио чувено Капетан Мишино здање на Студентском Тргу које данас служи као седиште Ректората Универзитета у Београду (Станковић, 2016: 304-306). Према попису из 2011. године, Доњи Милановац је имао 2410 становника, од чега велику већину чине Срби, а Власи представљају највећу мањинску групу.

На званичном сајту Великог Градишта (Cајт општине Велико Градиште, 2019), стоји да је Велико Градиште градско насеље и седиште истоимене општине у Браничевском округу. На северу је општина омеђена Дунавом који је у дужини од 20 километара раздваја од суседне Румуније. Сматра се да се овај град развио у најсевернијем и најплоднијем делу Браничева, у близини ушћа Пека у Дунав. Лежи на остацима римског насеља Pincum, важног утврђења и стационара Седме римске легије. Највећи процват Пинкум доживљава за време владавине цара Хадријана, а бакарни новчићи који су ковани у то време сачувани су у свега пет примерака, и данас се налазе у Бечу, Берлину, Лондону и Београду. Као погранично место ка Румунији, Велико Градиште се у 19. веку убрзано развијало захваљујући извозу пшенице, кукуруза и свиња преко Дунава, па је зато настала и потреба за отварањем царинарнице. Данас се становништво претежно бави пољопривредом на сопственим поседима, трговином, занатством и саобраћањем Дунавом, односно Ђердапским језером. Према попису из 2011. године, Велико Градиште имало је 5825 становника, највећим делом Срба (92\%), затим Влаха, Рома и Румуна у незнатном броју (Станковић, 2016: 282-284).

На самом почетку, осврнућемо се на основне појмове из области ономастике, као и дати детаљни приказ свеобухватне типологије топонима (Tent \& Blair, 2011). У наредним деловима, биће образложена примењена методологија, а затим ће сваки назив улице бити класификован на основу оригиналног (изворног) референта по коме је она и добила назив, што ће довести до упоредне класификације за сва испитана места. На крају, истраживачи ће понудити опште закључке на основу добијених резултата.

\section{МЕТОДОЛОГИЈА}

\section{Референтност, врсте значења и теорије именовањ а}

Имена представљају најочигледнији пример номиналних фраза које испољавају референтност као називи за људе, предмете, објекте, итд. Контекст игра важну улогу у употреби имена, тј. употребом неког имена, говорник претпоставља да ће слушаоци моћи да одреде референта који је он имао на уму. Властита имена која се односе на одређене објекте или особе називају се односним, или референтним терминима. Референт је, дакле, оно на шта референтност указује, док се сама референтност може дефинисати као однос између стварности 
у најширем смислу и језика (Saeed, 2003: 11). На основу овога, можемо претпоставити да сваки назив улице има изворног референта, па самим тим и етимолошко значење.

Кроз историју, даваоци имена су тим чином приписивали различите карактеристике онима или ономе шта су именовали, па се зато сматра да имена носе друштвени, историјски и дескриптивни значај. Андерсон (Anderson, 2007: 93) наводи да је у средњоенглеском периоду, започела традиција структурисања имена око личног имена и породичног презимена, што је довело до стварања сложеница (енгл. compound) које се могу односити на једног референта заједно, одвојено или у комбинацији са титулама или другим појединостима. Тако, једна иста особа, у зависности од контекста, може бити Џон, Џон Смит, г-дин Џон Смит, или само Смит. Андерсон (2007: 99) додаје и да извори имена осликавају различите функције именовања, као и да циљеви система именовања могу бити отеловљени у информацијама везаним за сама имена. То могу бити енциклопедијске информације (као што су околности рођења) или лексичке информације (као што је пол). Имена пре свега имају референтну, идентификациону функцију, али могу имати и прегршт других функција.

Багби и Сигалов (Bagby \& Sigalov, 1987: 474) тврде да властита имена садрже три врсте значења: етимолошко значење (енгл. etymological meaning), односно, право значење његовог корена; означавајуће значење (енгл. signifying meaning), тј. праву функцију властитог имена; као и друштвено значење (енгл. social meaning), или симболику имена које је усвојило неко специфично историјско значење у датој култури. Најважнијим од ове три врсте значења, сматра се друго, означавајуће, с обзиром на то да га сва властита имена садрже; етимолошко значење такође може бити заступљено, али до њега најчешће треба доћи ретроактивно, док је симболичко значење најмање заступљено. Бланар (Blanár, 2009: 105) наводи да постоје две групе елемената који се тичу информација које налазимо у властитим именима. Прва група састоји се од појединачно различитих елемената информација који омогућавају одређивање и издвајање појединачних онимијских објеката (нпр. године, висина, физички изглед, адреса, итд. дате особе). Иако ово знање није исто за говорника и слушаоца, постоји извесно преклапање у информацијама које они деле. Другу групу чине друштвено признати елементи значења, који не зависе од појединца, већ само од дате онимијске класе.

Један од задатака овог истраживања јесте да утврди како су дате улице добиле своје називе. Истраживање се ослања на описну теорију имена (Frege, 1991; Russell, 1991) и каузалну теорију референтности (Kripke, 1980). У описној теорији имена (енг. the descriptivist theory of names), име је назив за знање о референту или за једно или више коначних описа. Код ове теорије, разумевање имена и идентификовање референта зависе од повезивања имена са тачним описом или знањем (Saeed, 2003: 28). Каузална теорија референтности (енг. the causal theory of reference) потиче од Крипкеа (Kripke, 1980) и представља алтернативу описној теорији номиналне референтности. 
Према овој теорији, сва властита имена друштвено су наслеђена или позајмљена тако да сви носиоци датог имена формирају каузални (узрочни) ланац. Основна идеја ове теорије јесте да се употреба имена односи на било шта што је са њим повезано на одговарајући начин, односно, од говорника се не очекује да повеже било какав идентификациони описни садржај са именом (Kripke, 1980: 59).

\section{Топоними и класификачија топонима}

Топоними, односно називи места, представљају устаљене оријентире чија их трајност и непроменљивост чини важним подацима за историјска истраживања (El Fassi, 1984: 18-22). Што је још важније, топоними су сложене семиотичке структуре које појашњавају један слој значења колективног искуства. Ова значења могу се посматрати као аспекти колективног искуства групе, и то у географском, историјском, језичком, симболичком и друштвено-политичком смислу. Географски фактори углавном се односе на могућност недвосмисленог упућивања на географске појмове, без чега би свакодневни живот био знатно отежан (Raper, 1996: 150). Историјски фактори, као спој просторних и временских елемената, огледају се у називима који служе као језичке слике битних историјских догађаја. Језички аспект односи се на језик као посредно средство и складиште свих топонима, с обзиром на то да морфологија, синтакса и семантика једног језика у великој мери употпуњују значење. Ово значење представља дословно језичко значење имена, које заједно са симболичким чини целокупно ономастичко значење. Друштвено-политички фактори присутни су када дође до промене топонима са новом влашћу како би се избрисали идеолошки или симболички трагови претходног режима. Другим речима, нови топоними служе као показатељи на новопројектовану политичку стварност (Batoma, 2006: 1-3).

Међутим, на питање зашто неко место носи одређени назив јесте и најтеже одговорити управо због тога што разлози за давање имена често нису у потпуности познати, па се све своди на спекулације. Досадашња истраживања о топонимима не нуде јединствену свеобухватну, универзалну класификацију, нити предлажу класификацију која се односи на све културе, али ипак постављају неколико смерница које би требало узети у обзир приликом анализе, као што су само име, локација, извор именовања и језички елементи (морфологија, синтакса и семантика) (Tent \& Blair, 2011: 69). Свакако, прихватљива класификација мора да има довољно специфичних категорија које би покриле све топониме и које се међусобно не преклапају, као и да покаже разлике у мотивисаности за давање одређеног имена. Мотивисаност се може дефинисати као механизам или modus operandi иза процеса именовања, односно процедуре, методе, стратегије или изворни референти када су они доступни и познати (Tent \& Blair, 2011: 80-81). Имајући у виду интуитивне семантичке компоненте које су релевантне за мотивисаност топонима, као и термине за различите типове мотивисаности, Тент и Блер (Tent \& Blair, 2011: 84-85) прева- 
зилазе готово све недостатке дотадашњих класификација, и предлажу

9 категорија топонима са одговарајућим опционим поткатегоријама.

Ми ћемо сада дати детаљан преглед Тентове и Блерове класификације, са изостанком поткатегорија које су неприменљиве на контекст именовања топонима у Србији (Табела 1).

Табела 1.

\section{Типологија топонима}

0. Непознати - где су значење, референтност, референт или порекло топонима непознати;

1. Описни - који означавају неку истакнуту особину места;

1.1. Топографски - који описују физичке карактеристике места било квалитативно или метафорички;

1.2. Односни - који означавају положај места у односу на друго, хронолошки или просторно;

1.3. Локацијски - који означавају локацију или оријентацију места;

1.4. Нумерички/мерни - који броје или мере елементе места:

2. Асоцијативни - који означавају нешто што је увек или често повезано са физичким контекстом;

2.1. Локални - који означавају топографске, биолошке или истакнуте карактеристике места;

2.2. Занимање/активност - који означавају занимања или уобичајене активности места;

3. Догађајни - који означавају догађај, инцидент, повод (или датум) или активност повезану са местом;

3.1. Инцидент - који означавају догађај, инцидент или активност повезану са местом;

3.2. Повод (прилика) - који означавају време или датум повезан са местом;

4. Евалуациони - који означавају емотивну реакцију даваоца имена, или снажну конотацију повезану са местом;

4.1. Похвални - који означавају позитивну реакцију на место;

4.2. Осућујући - који означавају негативну реакцију на место;

5. Премештајни - употреба топонима, у целости или делимично, са другог места;

5.1. Преносни - пребачени са другог места;

5.2. Премештај места - преузети од суседног места другог типа;

6. Староседелачки (аутохтони) - који означавају староседелачке

топониме или речи;

7. Епоними - који означавају сећање на истакнуте личности, жива и

нежива бића коришћењем одговарајућег имена или титуле;

7.1. Личности - властита имена истакнутих личности и група;

7.2. Жива и нежива бића - који означавају властита имена живих и неживих бића;

8. Језичке иновације - који означавају нове језичке форме настале манипулацијом језика (амалгами, анаграми, хумор);

9. Погрешни - који означавају нове форме настале кроз погрешно тумачење, писање, итд.

\section{Истраживачки приступ}


Ово истраживање представља квалитативну и квантитативну анализу назива улица у из четири места (Босилеграда, Димитровграда, Доњег Милановца и Великог Градишта) ради испитивања да ли називи улица осликавају наглашену потребу за очувањем сопственог идентитета као саставног дела живота у пограничном појасу. Комплетни спискови свих улица по абецедном реду сва четири места доступни су на сајту План Плус (2018). Након приступања сваком од спискова понаособ, аутори су истраживали порекло сваког појединачног назива улице уз помоћ информација доступних на интернету, и то махом географских и историјских података са званичних презентација општина Босилеград, Димитровград, Мајданпек и Велико Градиште као најверодостојнијих извора, али и консултовањем самих житеља и запослених у туристичким организацијама датих места када другачије није било могуће доћи до информација. По одређивању изворног референта, називи су класификовани у одговарајуће категорије по узору на типологију топонима коју су предложили Тент и Блер (2011). Називи улица одабраних градова смештени су у скоро сваку од понуђених категорија из оригиналне класификације, са изузетком категорија које одговарају аутохтоним, погрешним и топонимима насталим језичким иновацијама, јер таквих, према примени класификације аутора, није било. Треба напоменути и да су изворни референти, нарочито у категорији премештајних топонима и епонима, наведени само у случајевима када се не ради о општепознатим географским појмовима (нпр. битно је појаснити назив Изворитица, што је назив добијен од истоимене речице, али назив није потребно појашњавати у случаују Aзије, која носи назив по једном од континената) или истакнутим личностима из мањинске, српске или светске историје (нпр. због већинског читалаштва појашњено је ко је Христо Ботев, бугарски песник и народни револуционар, док појашњења везаних за Вука Караиића није било). Такође, изворни референти су спецификовани и онда када је сматрано да није довољно јасно по чему је дата улица добила назив (нпр. Ђурчија која је назив добила по врсти занатлије који израђује одевне предмете од коже, у народу познатом као ћурчија или ђурчија).

\section{РЕЗУЛТАТИ}

\section{Босилеград}

У овом делу биће извршена класификација 41 назива улица Босилеграда, чији је списак улица доступан на сајту План Плус (2018). Као што се може приметити из дате класификације (Табела 2), највећи број улица у Босилеграду добио је свој назив премештањем неког другог топонима (18), затим на основу истакнутих личности (8), како из српске, тако и бугарске историје, битног датума - углавном значајних догађаја из доба СФРЈ (7), или занимања и активности које су се углавном одвијале на датом месту (4). Остале категорије нису заступљене у великој мери. Можда најочигледнији показатељ да се ради о месту смештеном у пограничном појасу јесте подједнак број улица 
које носе назив по истакнутим личностима из обе културе - бугарске

и српске. Иако се место већ скоро цели век налази на територији Републике Србије, нема сумње да је већинско бугарско становништво временом допринело изградњи сопственог идентитета кроз процесе именовања. Са друге стране, не може се тврдити ни да српска културна баштина нема свој израз у називима улица, нарочито када се ради о датумима који су обележавали битне догађаје из историје СФРЈ, али и о личностима важним за национални идентитет Срба.

\section{Табела 2.}

Квалитативна анализа назива улица Босилеграда

2 Асоцијативни - који означавају нешто што је увек или често повезано са физичким контекстом

2.1 Локални - који означавају топографске, биолошке или истакнуте карактеристике места (Јасиковаи)

2.2 Занимање/активност - који означавају занимања или уобичајене активности места (Индустријска, Пиљарска, Радничка, Самариијска) 3 Догађајни - који означавају догађај, инцидент, повод (или датум) или активност повезану са местом

3.2 Повод (прилика) - који означавају време или датум повезан са местом (22. децембар, 28. март, 29. новембар, 7. јул, 8. март, 8. септембар, Првомајска)

4 Евалуациони - који означавају емотивну реакцију даваоца имена, или снажну конотацију повезану са местом

4.1 Похвални - који означавају позитивну реакшију на место (Младост) 5 Премештајни - употреба топонима, у целости илл делимично, са другог места

5.1 Преносни - пребачени са другог места (Азија, Блат - по истоименом изворишту, Црноок - по истоименој планини и врху, Добри дол,

Добродолска, Добродолски поток - по истоименом потоку, Изворштица

- по истоименој речици, Карапин дол - по истоименом предграђу,

Краин дол, Кремиково - по истоименој махали и брду, Лештава - по

истоименом брду, Воденици - по истоименој махали, Породин - по

истоименом предграђу, Рисовица - по истоименом брду)

5.2 Премештај места - преузети од суседног места другог типа

(Грујински пут - по селу Грујинци, Југословенска, Кеј Драговиштица -

по истоименој реши, Параловски пут - по селу Паралово)

7 Епоними - који означавају сећање на истакнуте личности, жива и

нежива бића коришћењем одговарајућег имена или титуле

7.1 Личности - властита имена истакнутих личности и група

(Георги Димитров - по бугарском комунистичком вођи, Христо

Ботев - по бугарском песнику и народном револуционару, Иво Лола

Рибар, Мариала Тита, Николе Тесле, Славчо Динов - по учеснику

Народноослободилачке борбе у Другом светском рату, Васил Левски по бугарском револуционару и вођи борбе за ослобођење од османске владавине, Вука Каращића)

7.2 Жива и нежива бића - који означавају властита имена живих и неживих бића (Мутавцинц̧и, Радинц̧и - по истоименој фамилији) 


\section{Димитровград}

У овом делу биће извршена класификација 70 назива улица Димитровграда, чији је списак улица доступан на сајту План Плус (2018). Као што илуструје дата класификација (Табела 3), највећи број улица у Димитровграду добиле су свој назив на основу истакнутих личности (28), како из српске и бугарске, тако и међународне историје, затим преузимањем имена од топонима који означава други тип места (13), или потпуним преузимањем неког другог топонима (10), битног датума - углавном значајних догађаја из доба СФРЈ (6), али и истакнутих група неименованих припадника (6). С обзиром на то да је Димитровград још један град у близини Бугарске, са већинским бугарским становништвом, није изненађујуће што је бугарска културна заоставштина присутна у великој мери у називима његових улица. Међутим, српске истакнуте личности ипак су бројчано заступљеније када се ради о улицама које по њима носе називе. Присуство назива по међународно признатим заслужним грађанима може се објаснити неутралним решењем у демографски разноликој средини. Очување српског историјског идентитета у овом граду огледа се и у улицама чија имена означавају важне датуме у историји Југославије.

\section{Табела 3.}

Квалитативна анализа назива улица Димитровграда

2 Асоцијативни - који означавају нешто што је увек или често повезано са физичким контекстом

2.1 Локални - који означавају топографске, биолошке или истакнуте карактеристике места (Сребрна, Лозарска, Трг строшена чесма)

2.2 Занимање/активност - који означавају занимања или уобичајене

активности места (Граничар, Радничка, Железничка)

3 Догађајни - који означавају догађај, инцидент, повод (или датум) или активност повезану са местом

3.2 Повод (прилика) - који означавају време или датум повезан са местом (22. дечембар, 4. јұли, 8. март, 8. септембар, 9. мај, Првомајска)

4 Евалуациони - који означавају емотивну реакцију даваоца имена, или снажну конотацију повезану са местом

4.1 Похвални - који означавају позитивну реакцију на место (Борачка) 5 Премештајни - употреба топонима, у целости или делимично, са другог места

5.1 Преносни - пребачени са другог места (Бурел - по истоименом брдско-планинском земљишту, Јерма - по истоименој реци, Козарица

- по истоименом врху, Нишава, Стара планина, Сутјеска, Видлич - по истоименом брду, Висок - по истоименој просторној целини, Врело, Забрће - по просторној целини Забрђе)

5.2 Премештај места - преузети од суседног места другог типа (Балканска, Београдска, Царибродска, Црногорска, Градинска, Хиландарска, Косовска, Нешкова - по Нешковом брду, Нишка, Петерлашка - по насељеном месту општине Димитровград, Славјанска (српска), Софијска, Зеленгорска - по Зеленгори, планини у Босни и Херцеговини) 
7 Епоними - који означавају сећање на истакнуте личности, жива и нежива бића коришћењем одговарајућег имена или титуле 7.1 Личности - властита имена истакнутих личности и група (Бора Станковић, Бошко Буха, Бранко Ћопић, Десанка Максимовић, Детко Петров - по српском и бугарском књижевнику, Елин Пелин - по бугарском писцу, Флемингова, Христо Ботев - по бугарском песнику и народном револуционару, Христо Смирненски - по бугарском писцу и члану комунистичке партије, Иво Андрић, Каравелов - по бугарском писцу, Кирил Методи, Лазе Лазаревића, Најдена Кирова - по учеснику Народноослободилачке борбе у Другом светском рату, Његошева, Нушићева, Пастерова, Раковски - по Георги Сави Раковском, бугарском револуционару и писцу, Светосавска, Светозара Марковића, Теслина, Толстојева, Трг доктора Зорана Ђинђића, Васил Иванов Циле - по учеснику Народноослободилачке борбе у Другом светском рату, Васил Левски - по бугарском народном хероју и револуционару у борби против отоманске владавине, Власки Алексов - по учеснику Народноослободилачке борбе у Другом светском рату, Вука Караџића, Живко Ропотски - по првом учитељу у ОШ „Христо Ботев“") 7.2 Жива и нежива бића - који означавају властита имена живих и неживих бића (Босутских жртава, Царибродских уметника, ЈНА, Омладинских бригада, Партизанска, Шопска - по Шопима: Бугарима, Македонцима и Србима из шопске регије)

\section{Доњи Милановач}

У овом делу биће извршена класификација 45 назива улица Доњег Милановца, чији је списак улица доступан на сајту План Плус (2018). У датој класификацији (Табела 4), примећује се да је готово половина свих улица своје називе добила по истакнутим личностима (22), и то искључиво из српске и југословенске историје. Иако се ради о граду у близини границе са Румунијом, претежно српско становништво условило је и потпуну доминантност српског националног и културног идентитета у именима улица. Као и у претходним градовима, велики број улица носи назив по другим местима различите врсте. Такође, у овом граду, присутна је и описна категорија, за разлику од претходних.

\section{Табела 4.}

Квалитативна анализа назива улица Доњег Милановца

1 Описни - који означавају неку истакнуту особину места

1.1 Топографски - који описују физичке карактеристике места било

квалитативно или метафорички (Хладне воде, Студена)

2 Асоцијативни - који означавају нешто што је увек или често повезано са физичким контекстом

2.2 Занимање/активност - који означавају занимања или уобичајене активности места (Бурчија - по врсти заната, Радничка) 
3 Догађајни - који означавају догађај, инцидент, повод (или датум) или активност повезану са местом

3.2 Повод (прилика) - који означавају време или датум повезан са местом (1. маја, 9. Октобра, Албанске споменице - по медаљи за спомен на повлачење српске војске преко Албаније, односно, једностепеном државно-војном и цивилном одликовању које су стекли сви припадници српске војске који су се повлачили преко Албаније у зиму 1915/1916.) 4 Евалуациони - који означавају емотивну реакцију даваоца имена, или снажну конотацију повезану са местом 4.2 Осуђујући - који означавају негативну реакцију на место (Хладне воде, Студена)

5 Премештајни - употреба топонима, у целости или делимично, са другог места

5.1 Преносни - пребачени са другог места (Циганија - по истоименом археолошком налазишту, Црвена бара - по Букуљском језеру или Црвеној бари у близини Аранђеловца, Казански поток - по истоименом насељу, Лепенски вир, Орешковица - по истоименом селу, Папреница - по истоименом превоју, Варошки поток, Запис - по истоименом подручју/селу, Златно језеро - по језеру у националном парку Ђердап)

5.2 Премештај места - преузети од суседног места другог типа (Ђердапска, Дунавска, Мајданпечки пут, Мирочка, Поречка - по крају Пореч, Рудноглавски пут - по насељу Рудна Глава)

7 Епоними - који означавају сећање на истакнуте личности, жива и нежива бића коришћењем одговарајућег имена или титуле 7.1 Личности - властита имена истакнутих личности и група (Цвете Николић - по учесници Народноослободилачке борбе у Другом светском рату, Хајдук Вељкова, Иве Стојановића - по учеснику Народноослободилачке борбе у Другом светском рату, Јована Цвијића, Капетана Мише, Капетана Тенке - по Стефану Стефановићу Тенки, познатом русофилу и заверенику у плану за убиство кнеза Александра Карађорђевића, Карађорђева, Кнеза Милоша, Краља Петра Првог, Миленка Стојковића - по револуционару из Првог српског устанка, Немањина, Николе Пашића, Николе Тесле, Старине Новака, Стевана Мокрањиа, Светог Саве, Светозара Марковића, Васе Чарапића, Васе Пелагића, Војводе Мишића, Вука Караиића, Змај Јовина)

7.2 Жива и нежива бића - који означавају властита имена живих и неживих бића (16. бригаде)

\section{Велико Градиште}

У овом делу биће извршена класификација 110 назива улица Великог Градишта, чији је списак улица доступан на сајту План Плус (2018). На основу дате класификације (Табела 5), може се приметити да највећи број улица овог града носи назив по истакнутим личностима и заслужним грађанима, и то искључиво из српске и југословенске историје, што и није изненађујуће с обзиром на демографску структуру овог града. Као и у случају Доњег Милановца, претежно српско становништво условило је и велику заступљеност српског националног и културног идентитета у именовању улица. Такође, велики број топонима преузет је од назива места друге врсте, а интересантне су и улице које су називе добиле по активностима заступљеним у овом месту. Наиме, називи као што су Аласка или Рибарска у складу су са традиционалним занимањима житеља Великог Градишта као општи- 
не на обали Дунава.

Табела 5.

Квалитативна анализа назива улица Великог Градишта

1 Описни - који означавају неку истакнуту особину места

1.2 Односни - који означавају положај места у односу на друго, хронолошки или просторно (Мали расадник, Стари бели багрем)

1.4 Нумерички/мерни - који броје или мере елементе места (1. Рударево, 2. Рударево, 3. улича)

2 Асоцијативни - који означавају нешто што је увек или често повезано са физичким контекстом

2.1 Локални - који означавају топографске, биолошке или истакнуте карактеристике места (Бунгаловска, Градско сокаче, Језерска, Ритска, Виноградска, Житни трг)

2.2 Занимање/активност - који означавају занимања или уобичајене активности места (Аласка, Ловачка, Рибарска, Шеталачка)

3 Догађајни - који означавају догађај, инцидент, повод (или датум) или активност повезану са местом

3.1 Инцидент - који означавају догађај, инцидент или активност повезану са местом (Трг ослобођења)

3.2 Повод (прилика) - који означавају време или датум повезан са местом (11. октобра, Првомајска)

4 Евалуациони - који означавају емотивну реакцију даваоца имена, или снажну конотацију повезану са местом

4.1 Похвални - који означавају позитивну реакцију на место (Језерска звезда, Сунчани брег, Трг ослобођења)

4.2 Осуђујући - који означавају негативну реакцију на место (Гробљанска)

5 Премештајни - употреба топонима, у целости или делимично, са другог места 5.1 Преносни - пребачени са другог места (Пећка патријариија, Пинкум - по истоименом римском утврђењу, Рударево - по истоименом насељу)

5.2 Премештај места - преузети од суседног места другог типа (Банатска, Београдска, Браничевска, Бољетинска - по насељу Бољетин, Церска, Дринска, Добранска - по селу Добран, Дунавска, Градиштанска, Карпатска, Крфска, Кусићки nут - по насељу Кусић, Млавска, Молдавска, Моравска, Печка - по реци Пек, Пожаревачки пут, Призренска, Пут за Сребрно језеро, Раиска, Раваничка,

Равногорска, Сарајевска, Скопьанска, Сремска, Шумадинска, Жичка)

7 Епоними - који означавају сећање на истакнуте личности, жива и нежива бића коришћењем одговарајућег имена или титуле

7.1 Личности - властита имена истакнутих личности и група (Андре Љубичића - по народном посланику из доба Првог светског рата и свештенику, Благе Стеєића - по организатору устанка у Другом светском рату, Боика Бухе, Боика Вребалова - по учеснику Народноослободилачке борбе у Другом светском рату, Божидара Димитријевића Козиие - по учеснику Народноослободилачке борбе у Другом светском рату, Браће Буђони - по учесницима Народноослободилачке борбе у 
Другом светском рату, Браће Ђорђекић- по Павлу и Ђорђу Ђорђевићу који су сву своју имовину у XX веку оставили Великом Градишту са циљем оснивања музеја, ЦІара Дуиана, LІеијићеєа, Дииитрија Трифуновића - по народном хероју п следбенику Светозара Марковића, познатијем под надимком „Уча “ у селу Рам Општине Велико Градиште, Доситејева, Буре Јакийа, Хајдук Вељкова, Јоче Селий - по народном посланику Народне скупштине на Крфу 1916. године, Капетан

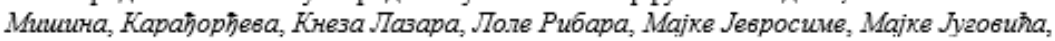
Михајла Пупина, Милене Павловй Барити, Митивоја Сииеуновиһа - по настрадалом/несталом учеснику Другог светског рата, Мирка Матића - по борцу и авијатнчару из Другог светског рата, Мирослава Tupuа, Huколе Tecre, Његоиева, Нуийева, Обала крава Петра, Обитииева, Павла Савйа - по српском физичару и хемичару, Пере Металца - по полицијском комесару и припаднику комунистичке партије што означава „Металац“, Професора Милинкобйа - по Миодрагу Милинковићу, професору Општине Велико Градиште и итегалном партијском раднику стрељаном у Народноослободилачкој борби, Саве Ковачебића, Caбe Обрадоєића - по задужбинару који је поклонио зграду некадашпе апотеке где је данас смештена библиотека Великог Градишта, Синбелићева, Старине Новака, Стефана Дечанское, Столета Опанчара - по синдикапном борцу за радничка права и организатору великог народног штрајка опанчара, Светосавска, Тре Мияоја Васића - по српском археалогу, Тре Младена Миторадовйа - по првоборцу

Народноослободилачке борбе погинулом на Сутјесци, Вељка Дуеоиебића - по учеснику Народноослободилачке борбе у Другом светском рату, Вељка Влахкоєйапо црногорском плану Комунистиче партије, Властииира Пабловића Царевца - по српском виолинисти, диригенту и оснивачу Народног оркестра Радио Београда, Воје Бовданоєића - по учеснику Народноослободилачке борбе у Другом светском рату, Bојеоде Добрњиа, Војеоде Митенка, Bојєоде Мииића, Bојбоде Путника, Војбоде Cmепе, Вука Карацйа, Жике Динйа Бабиное - по председнику Општине Велико Градиште који је извршио регулацију улица и прпјатељу Николе Пашића, Жuке Попоєйа - по професору Шабачке гимназије, Жикиуе Јобанобића Шиануа) 7.2 Жива и нежива- који означавају властита имена живих и неживих бића (Албанске спомениче, Младих горана, Солунских ратника, Тре пролетерских бригада)

У Табели 6 дат је квантитативни приказ категорија и поткатегорија присутних у сваком од истражених градова.

Табела 6 .

Квантитативни приказ категорија

\begin{tabular}{|c|c|c|c|c|}
\hline $\begin{array}{l}\text { Mecro } \rightarrow \\
\text { TиII, }\end{array}$ & Босилеград & Димитровград & $\begin{array}{l}\text { Доњи } \\
\text { Милановац }\end{array}$ & $\begin{array}{l}\text { Велико } \\
\text { Грапиште }\end{array}$ \\
\hline Опнсни & 0 & 0 & 2 & 5 \\
\hline Топографски & 0 & 0 & 2 & 0 \\
\hline Односни & 0 & 0 & 0 & 2 \\
\hline Нумерички/мерни & 0 & 0 & 0 & 3 \\
\hline Асоцијативни & 5 & 6 & 2 & 10 \\
\hline Локални & 1 & 3 & 0 & 6 \\
\hline Заннмање/активност & 4 & 3 & 2 & 4 \\
\hline Догађајни & 7 & 6 & 3 & 3 \\
\hline Инцидент & 0 & 0 & 0 & 1 \\
\hline Повод/прнлика & 7 & 6 & 3 & 2 \\
\hline Евалуациони & 1 & 1 & 2 & 4 \\
\hline Похвални & 1 & 1 & 0 & 3 \\
\hline Ocyђуіући & 0 & 0 & 2 & 1 \\
\hline Премештајни & 18 & 23 & 15 & 30 \\
\hline Преносни & 14 & 10 & 9 & 3 \\
\hline Премештај места & 4 & 13 & 6 & 27 \\
\hline Епоннми & 10 & 34 & 23 & 59 \\
\hline Личности & 8 & 28 & 22 & 55 \\
\hline Жива и нежива 6 ића & 2 & 6 & 1 & 4 \\
\hline
\end{tabular}




\section{ЗАКЉУЧАК}

У складу са одабраном типологијом, може се приметити да су категорије премештајних топонима и епонима доминантне у свим градовима, при чему премештајних највише има у Великом Градишту и Димитровграду, а нешто мање у Босилеграду и Доњем Милановцу. Што се тиче епонима, приметан број улица у Великом Градишту добио је назив по некој истакнутој личности; слично је и у Димитровграду и Доњем Милановцу, док је број епонима најмањи у Босилеграду. Остале категорије нису присутне у мери која би наговестила неку значајну разлику, сем можда у случају асоцијативних топонима у Великом Градишту. Такође, треба имати на уму да је бројно стање унутар категорија одраз броја улица у самим градовима, у чему предњачи Велико Градиште као град са највећим бројем улица.

На основу анализе претраженог корпуса, можемо закључити да је демографска структура становништва у местима на граници Србије и Бугарске, Босилеграду и Димитровграду, довела до готово уједначеног израза тежњи за очувањем националног идентитета Бугара, као већинског становништва у овим општинама, тако и Срба, као мањинског становништва у овим општинама, али већинског на нивоу Републике Србије. Ова појава највише је заступљена у улицама које носе називе по истакнутим личностима из обе културе. Међутим, када се ради о осталим категоријама, доминантни су српски језик, етимологија и историја, што је прилично интересантно с обзиром на то да већинско становништво у оба града чине Бугари. Са друге стране, места у близини границе са Румунијом, у великој мери насељена српским становништвом, не показују веће трагове влашког и румунског културног утицаја, већ искључиво српског, што је приметно у готово свим категоријама. Ово и није тако изненађујући податак с обзиром на то да Власи и Румуни чине мање етничке групе у овим местима, упркос географској близини са Румунијом.

\section{ЛИТЕРАТУРА}

Anderson, J. M. The Grammar of Names. Oxford: Oxford University Press, 2007.

Bagby, L., \& P. Sigalov. "The Semiotics of Names and Naming in Tolstoj's 'The Cossacks"'. The Slavic and East European Journal 31, 4, (1987): 473-489.

Batoma, A. "African Ethnonyms and Toponyms: An Annotated Bibliography". Electronic Journal of Africana Bibliography 10, 2006. Available at: https://ir.uiowa.edu/cgi/viewcontent. cgi?article=1000\&context=ejab, приступљено 23. 12. 2018.

Blanár, V. Proper Names in the Light of Theoretical Onomastics. Martin: Matica Slovenská, 2009.

El Fassi, M. "Toponymy and Ethnonymy as Scientific Aids to History". African Ethnonyms and Toponyms: Report and Papers of the Meeting of 
Experts 1984: 18-22. Paris: UNESCO.

Frege, G. "On Sense and Nominatum”. In Meaning and Truth: Essential Readings in Modern Semantic, edited by J. L. Garfield and M. Kiteley, 35-53. New York: Paragon House, 1991.

Kripke, S. Naming and Necessity. Cambridge, MA: Harvard University Press, 1980.

Raper, P. E. United Nations Documents on Geographical Names. Pretoria: Names Research Institute, 1996.

Russell, B. “On Denoting”. In Meaning and Truth: Essential Readings in Modern Semantics, edited bx J. L. Garfield and M. Kiteley, 87-103. New York: Paragon House, 1991.

Saeed, J. I. Semantics, $2^{\text {nd }}$ ed. Blackwell Publishing, 2003.

Станковић, С. Србија. Градови. Опитине. Насеља. Београд: Службени гласник, 2016.

Tent, J., \& D. Blair. "Motivations for Naming: The Development of a Toponymic Typology for Australian Placenames". Names 59, 2 (2011): 67-89.

\section{Општине}

Општина Босилеград

http://www.bosilegrad.org/sr/OBosilegradu.aspx, приступљено 12. 1. 2019. год.

Општине Димитровград

http://www.dimitrovgrad.rs/cir/onama, приступљено 12. 1. 2019. год.

Општина Мајданпек http://www.majdanpek.rs/index.php?option=com_co ntent\&view $=$ article \&id=60:geografski-polozaj\&catid=92:2011-04-14-0718-21\&Itemid=94, приступљено 14. 1. 2019. год.

Општина Велико Градиште

http://velikogradiste.rs/opsti-podaci/, приступљено 14. 1. 2019. год.

План Плус (индекс улица)

Босилеград

https://www.planplus.rs/bosilegrad/bosilegrad/ulice, приступљено 12. 1. 2019. год.

Димитровград

https://www.planplus.rs/dimitrovgrad/dimitrovgrad/ulice, приступљено 12. 1. 2019. год.

Доњи Милановац

https://www.planplus.rs/majdanpek/donji-milanovac/ulice, приступљено 14. 1. 2019. год.

Велико Градиште https://www.planplus.rs/veliko-gradiste/veliko-gradiste/ulice, приступљено 14. 1. 2019. год.

Попис у Србији 2011. године http://pod2.stat.gov.rs/ObjavljenePublikacije/Popis2011/Nacionalna\%20 pripadnost-Ethnicity.pdf, приступљено 16. 1. 2019. год. 


\title{
STREET NAMES IN THE BORDERLINE PLACES OF EASTERN AND SOUTHEASTERN SERBIA
}

\begin{abstract}
Summary
The main aim of this study is to take the perspective of onomastics and sociolinguistics and examine the toponyms in two places on the border between Serbia and Bulgaria (Bosilegrad and Dimitrovgrad) and Serbia and Romania (Donji Milanovac and Veliko Gradište). The study is based on the corpus consisting of all the street names of the four chosen places. Based on the toponym typology suggested by Tent \& Blair (2011), and determining the original referent, the study offers a corresponding classification of street names. With the exception of certain specificities, we find that street names in the borderline areas reflect the need for preserving and highlighting both the Serbian cultural and historical heritage and the cultural and historical heritage of the local community.
\end{abstract}

Key words: street name, toponym, naming, borderline areas, identity. 